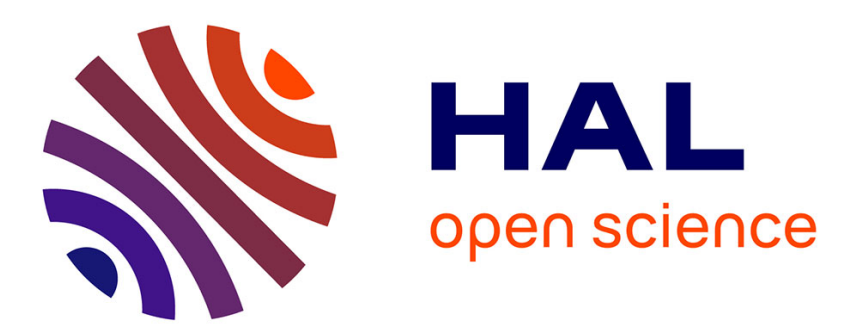

\title{
Centennial celebration of the bacteriophage research
}

Laurent Debarbieux, Patrick Forterre, Mart Krupovic, Mzia Kutateladze, David Prangishvili

\section{To cite this version:}

Laurent Debarbieux, Patrick Forterre, Mart Krupovic, Mzia Kutateladze, David Prangishvili. Centennial celebration of the bacteriophage research. Research in Microbiology, 2018, 169 (9), pp.479-480. 10.1016/j.resmic.2018.10.001 . pasteur-01977326

HAL Id: pasteur-01977326

https://hal-pasteur.archives-ouvertes.fr/pasteur-01977326

Submitted on 10 Jan 2019

HAL is a multi-disciplinary open access archive for the deposit and dissemination of scientific research documents, whether they are published or not. The documents may come from teaching and research institutions in France or abroad, or from public or private research centers.
L'archive ouverte pluridisciplinaire HAL, est destinée au dépôt et à la diffusion de documents scientifiques de niveau recherche, publiés ou non, émanant des établissements d'enseignement et de recherche français ou étrangers, des laboratoires publics ou privés.

$$
\text { Copyright }
$$




\section{Centennial celebration of the bacteriophage research}

The year 2017 marked the $100^{\text {th }}$ anniversary of the publication of Félix d'Herelle entitled "On an invisible microbe antagonistic toward dysenteric bacilli" in which he coined the term "bacteriophage" [1]. Who should be credited as the first discoverer of bacteriophages - Félix D'Herelle in 1917, Frederik Twort in 1915, Nikolay Gamaleya in 1898, Ernest Hankin in 1896, or perhaps an unknown scientist before them [1] - remains an open question. However, it is generally accepted that Félix d'Herelle's report in 1917 is a foundational article initiating bacteriophage research worldwide. Importantly, the same report outlined the fundamental principles of phage therapy by briefly mentioning the first use of bacteriophages to cure an experimental bacterial infection in animals (rabbits) [2].

In April 2017 and June 2017, at Institut Pasteur in Paris and Eliava Institute in Tbilisi, respectively, two conferences were organized to celebrate the centennial anniversary of bacteriophage research. These two international events attracted more than 400 participants from over 30 countries, demonstrating the renewed interest of scientists around the globe in studying bacteriophages and, more broadly, viruses of microorganisms (www.isvm.org). This renaissance of microbial virus research is largely instigated by two major developments: first, the growing appreciation of the abundance of microbial viruses and their impact on the global ecology, from the deep ocean to human gut [3-9]; and second, the recognition of bacteriophages as powerful therapeutic agents for treating infections caused by worrisome, antibiotic-resistant, pathogenic bacteria [10-13]. The coupling of the fundamental and applied research lines in exploration of the vast world of microbial viruses is particularly fruitful as exemplified by the burgeoning development of the CRISPR-Cas-based genome editing technologies $[14,15]$ or the discovery of new expansive families of microbial viruses, including crAssphages [16,17], the "Autolykiviridae" [18], and many others [19-26].

In this special issue of Research in Microbiology, we present a collection of papers reflecting the diversity of research lines focusing on microbial viruses. Kropinski [27] and Almeida et al. [28] provide historical overviews of different aspects of bacteriophage research and define new lines for future studies; Toussaint and Van Gijsegem [29], Atanasova et al. [30], and Buttimer et al. [31] describe novel microbial viruses and proviruses, providing further insights into the evolution and diversity of the corresponding virus families; Tkhilaishvili et al. [32] and Vinner and Malik [33] describe novel technological developments in bacteriophage research; whereas Gelman et al. [34] and Hoyle et al. [35] focus on the therapeutic potential of bacteriophages against diverse bacterial pathogens in different models, including a case report of successful treatment of a cystic fibrosis patient. We hope that these articles will inspire more scientists to join the growing community of microbial virologists and perpetuate the exciting research on microbial viruses for the next 100 years.

\section{Conflict of interest}

The authors declare no conflict of interest.

\section{References}

[1] Sulakvelidze A, Alavidze Z, Morris Jr JG. Bacteriophage therapy. Antimicrob Agents Chemother 2001;45:649-59.

[2] D'Herelle F. On an invisible microbe antagonistic toward dysenteric bacilli: brief note by Mr. F. D'Herelle, presented by Mr. Roux. 1917. Res Microbiol 2007; $158: 553-4$.

[3] Danovaro R, Dell'Anno A, Corinaldesi C, Magagnini M, Noble R, Tamburini C, et al. Major viral impact on the functioning of benthic deep-sea ecosystems, Nature 2008;454:1084-7.

[4] Danovaro R, Dell'Anno A, Corinaldesi C, Rastelli E, Cavicchioli R, Krupovic M, et al. Virus-mediated archaeal hecatomb in the deep seafloor. Sci Adv 2016;2:e1600492.

[5] Manrique P, Dills M, Young MJ. The human gut phage community and its implications for health and disease. Viruses 2017;9.

[6] Chow CE, Suttle CA. Biogeography of viruses in the sea. Annu Rev Virol 2015;2:41-66.

[7] Rohwer F, Thurber RV. Viruses manipulate the marine environment. Nature 2009;459:207-12.

[8] Trubl G, Jang HB, Roux S, Emerson JB, Solonenko N, Vik DR, et al. Soil viruses are underexplored players in ecosystem carbon processing. mSystems 2018;3.

[9] Roux S, Brum JR, Dutilh BE, Sunagawa S, Duhaime MB, Loy A, et al. Ecogenomics and potential biogeochemical impacts of globally abundant ocean viruses. Nature 2016;537:689-93.

[10] Roach DR, Debarbieux L. Phage therapy: awakening a sleeping giant. Emerg Top Life Sci 2017;1:93-103.

[11] Kilcher S, Loessner MJ. Engineering bacteriophages as versatile biologics. Trends Microbiol 2018 [in press].

[12] De Smet J, Hendrix H, Blasdel BG, Danis-Wlodarczyk K, Lavigne R. Pseudomonas predators: understanding and exploiting phage-host interactions, Nat Rev Microbiol 2017;15:517-30.

[13] Brussow H. Phage therapy for the treatment of human intestinal bacterial infections: soon to be a reality? Expert Rev Gastroenterol Hepatol 2017;11: 785-8.

[14] Heidenreich M, Zhang F. Applications of CRISPR-Cas systems in neuroscience. Nat Rev Neurosci 2016;17:36-44.

[15] Knott GJ, Doudna JA. CRISPR-Cas guides the future of genetic engineering. Science 2018:361:866-9.

[16] Dutilh BE, Cassman N, McNair K, Sanchez SE, Silva GG, Boling L, et al. A highly abundant bacteriophage discovered in the unknown sequences of human faecal metagenomes. Nat Commun 2014;5:4498.

[17] Yutin N, Makarova KS, Gussow AB, Krupovic M, Segall A, Edwards RA, et al. Discovery of an expansive bacteriophage family that includes the most abundant viruses from the human gut. Nat Microbiol 2018;3:38-46.

[18] Kauffman KM, Hussain FA, Yang J, Arevalo P, Brown JM, Chang WK, et al. A major lineage of non-tailed dsDNA viruses as unrecognized killers of marine bacteria. Nature 2018;554:118-22.

[19] Philosof A, Yutin N, Flores-Uribe J, Sharon I, Koonin EV, Beja O. Novel abundant oceanic viruses of uncultured marine group II euryarchaeota. Curr Biol $2017 ; 27: 1362-8$. 
[20] Prangishvili D, Bamford DH, Forterre P, Iranzo J, Koonin EV, Krupovic M. The enigmatic archaeal virosphere. Nat Rev Microbiol 2017;15:724-39.

[21] Creasy A, Rosario K, Leigh BA, Dishaw LJ, Breitbart M. Unprecedented diversity of ssDNA phages from the family microviridae detected within the gut of a protochordate model organism (ciona robusta). Viruses 2018:10.

[22] Wagner C, Reddy V, Asturias F, Khoshouei M, Johnson JE, Manrique P, et al. Isolation and Characterization of Metallosphaera turreted icosahedral virus (MTIV), a founding member of a new family of archaeal viruses. J Virol 2017;91. e00925-17.

[23] Wang H, Guo Z, Feng H, Chen Y, Chen X, Li Z, et al. A novel Sulfolobus virus with an exceptional capsid architecture. J Virol 2017;92. e01727-17.

[24] Laanto E, Mantynen S, De Colibus L, Marjakangas J, Gillum A, Stuart DI, et al. Virus found in a boreal lake links ssDNA and dsDNA viruses. Proc Natl Acad Sci U S A 2017; 114:8378-83.

[25] Holmfeldt K, Solonenko N, Shah M, Corrier K, Riemann L, Verberkmoes NC, et al. Twelve previously unknown phage genera are ubiquitous in global oceans. Proc Natl Acad Sci U S A 2013;110:12798-803.

[26] Aalto AP, Bitto D, Ravantti JJ, Bamford DH, Huiskonen JT, Oksanen HM. Snapshot of virus evolution in hypersaline environments from the characterization of a membrane-containing Salisaeta icosahedral phage 1. Proc Natl Acad Sci U S A 2012;109:7079-84.

[27] Kropinski AM. Bacteriophage research - what we have learnt and what still needs to be addressed. Res Microbiol 2018:169:481-7.

[28] Almeida GM, Leppanen M, Maasilta IJ, Sundberg LR. Bacteriophage imaging: past, present and future. Res Microbiol 2018;169:488-94.

[29] Toussaint A, Van Gijsegem F. Extension of the transposable bacterial virus family: two genomic organisations among phages and prophages with a Tn552-related transposase. Res Microbiol 2018;169:495-9.

[30] Atanasova NS, Demina TA, Krishnam Rajan Shanthi SNV, Oksanen HM, Bamford DH. Extremely halophilic pleomorphic archaeal virus HRPV9 extends the diversity of pleolipoviruses with integrases. Res Microbiol 2018;169: 500-4.

[31] Buttimer C, Born Y, Lucid A, Loessner MJ, Fieseler L, Coffey A. Erwinia amylovora phage vB EamM Y3 represents another lineage of hairy Myoviridae. Res Microbiol 2018;169:505-14.
[32] Tkhilaishvili T, Di Luca M, Abbandonato G, Maiolo EM, Klatt AB, Reuter M et al. Real-time assessment of bacteriophage T3-derived antimicrobial activity against planktonic and biofilm-embedded Escherichia coli by isotherma microcalorimetry. Res Microbiol 2018;169:515-21.

[33] Vinner GK, Malik DJ. High precision microfluidic microencapsulation of bacteriophages for enteric delivery. Res Microbiol 2018;169:522-30.

[34] Gelman D, Beyth S, Lerer V, Adler K, Poradosu-Cohen R, CoppenhagenGlazer S, et al. Combined bacteriophages and antibiotics as an efficient therapy against VRE Enterococcus faecalis in a mouse model. Res Microbiol 2018:169:531-9.

[35] Hoyle N, Zhvaniya P, Balarjishvili N, Bolkvadze D, Nadareishvili L Nizharadze D, et al. Phage therapy against Achromobacter xylosoxidans lung infection in a patient with cystic fibrosis: a case report. Res Microbiol 2018:169:540-2.

Laurent Debarbieux*, Patrick Forterre, Mart Krupovic Department of Microbiology, Institut Pasteur, 75015 Paris, France

Mzia Kutateladze

G. Eliava Institute of Bacteriophages, Microbiology and Virology, Tbilisi, Georgia

David Prangishvili Department of Microbiology, Institut Pasteur, 75015 Paris, France

* Corresponding author. E-mail address: laurent.debarbieux@pasteur.fr (L. Debarbieux).

19 October 2018 Available online 2 November 2018 